\title{
Hypertension and COVID-19: Current Evidence and Perspectives
}

\author{
Giovanna Gallo $^{1} \cdot$ Valentin Calvez $^{1} \cdot$ Carmine Savoia $^{1}$ (1)
}

Received: 15 November 2021 / Accepted: 10 December 2021 / Published online: 20 February 2022

(c) The Author(s) 2022

\begin{abstract}
Coronavirus disease 2019 (COVID-19) outbreak, caused by severe acute respiratory syndrome coronavirus 2 (SARS-CoV-2), represents a real challenge for health-care systems worldwide. Male sex, older age and the coexistence of chronic comorbidities have been described as the most relevant conditions associated with a worse prognosis. Early reports suggested that hypertension might represent a risk factor for susceptibility to SARS-CoV-2 infection, a more severe course of COVID-19 and increased COVID-19-related deaths. Nevertheless, the independent role of hypertension remains under debate, since hypertension is often associated with the older age and other cardiovascular (CV) risk factors in the general population, which may also contribute to the SARS-Cov-2 infection and COVID-19. Moreover, the role of antihypertensive drugs, primarily angiotensin-converting inhibitors (ACEIs) and ARBs (angiotensin receptor blockers) in COVID-19 development and outcome appears controversial. Indeed, preclinical studies using these classes of drugs have suggested a potential upregulation of angiotensin-converting-enzyme 2 (ACE2) which is the key binding receptor promoting cell entry of SARS-CoV-2 in the organism. Renin-angiotensin system (RAS) blockers may potentially upregulate ACE2, hence, it has been initially hypothesized that these agents might contribute to a higher risk of SARS-CoV-2 infection and progressive course of COVID-19. However, several clinical reports do not support a detrimental role of RAS blockers in COVID-19, and an intense debate about the withdrawal or maintenance of chronic therapy with ACEi/ARB has been developed. In this review we will discuss the available evidence on the role of hypertension and antihypertensive drugs on SARS-CoV-2 infection and COVID-19 development.
\end{abstract}

Keywords COVID-19 $\cdot$ High blood pressure $\cdot$ Renin-angiotensin system $\cdot$ ACE2 $\cdot$ MasR $\cdot$ RAS blockers

\section{Introduction}

The coronavirus disease 2019 (COVID-19) pandemic, caused by the severe acute respiratory syndrome coronavirus 2 (SARS-CoV-2) [1], poses unprecedented challenges to health-care systems around the world. As of 21 st October 2021, there have been more than 240 millions confirmed cases of COVID-19, including 5 millions deaths worldwide [2].

Several reports, over the past months, have shown that hypertension can be associated with the risk of SARS-CoV-2 infection as well as to the development of the worse prognosis of COVID-19 [3-6]. Nevertheless, these assumptions

Carmine Savoia

carmine.savoia@uniroma1.it

1 Cardiology Unit, Department of Clinical and Molecular Medicine, Faculty of Medicine and Psychology, Sant'Andrea Hospital, Sapienza University of Rome, Rome, Italy have been challenged and the independent role of hypertension on the risk of infection and the worse outcome of COVID-19 has been mitigated and under debate. In several observational studies hypertension is often associated with other CV risk factors and the older age since these conditions often coexist in the general population worldwide. Indeed, an increased risk of SARS-Cov-2 infection and worse outcomes of COVID-19, consisting in a higher risk of hospitalization, access to intensive care units and mortality, have been shown in the elderly and in individuals affected by comorbidities other than hypertension such as diabetes, previous cardiovascular (CV) and cerebrovascular diseases, obesity, and chronic pulmonary diseases [7-9].

Moreover, the role of the first-line agents for the treatment of hypertension [10-12] including ACE (angiotensin-converting enzyme) inhibitors (ACEIs) and angiotensin receptor blockers (ARBs) appears controversial in COVID-19. Indeed, preclinical studies using these Renin-Angiotensin System (RAS) antagonists have shown a potential induction 
of ACE2 (angiotensin-converting-enzyme 2) upregulation which is the key binding site promoting cell entry of SARSCoV-2 in the organism $[13,14]$. Thus, it has been thought that a putative upregulation of ACE2 in hypertensive patients during treatment with RAS-blockers might potentially contribute to the higher risk of SARS-CoV-2 infections and progressive course of COVID-19. However, several clinical reports do not support the notion of the detrimental role of RAS blockers in COVID-19. Thus, taken into account the widespread use of RAS inhibitors in patients with hypertension and CVD, an intense debate has developed about the withdrawal or maintenance of chronic ACEI/ARB therapy in patients with COVID-19 $[15,16]$.

In this review we will discuss the available evidence on the role of hypertension and blood pressure (BP) lowering drugs on SARS-CoV-2 infection and disease course of COVID-19.

\section{Role of Hypertension and Organ Damage in COVID-19 Outcome}

The first case series from China have reported that hypertension is the most common condition in patients affected by COVID-19, ranging from 27 to $30 \%$ while other comorbidities were considerably less represented (i.e. diabetes in $19 \%$, coronary artery disease [CAD] in 6-8\%) [7, 8]. In an observational study conducted in a cohort of 12,594 patients in New York City, hypertension was reported in a 34.6\% [17]. However, hypertension was frequently reported in association with diabetes particularly in patients who experienced a more severe disease course, admitted to intensive care units, and receiving mechanical ventilation or even dying. The association between COVID-19 and hypertension appears not surprising and does not necessarily imply a causal relationship, due to the large prevalence of high-BP worldwide, affecting $25 \%$ of the adult population with a peak of prevalence $>60 \%$ in the elderly population [18]. Thus, hypertension more frequently occurs in the elderly and in subjects affected by other comorbidities, who are the categories in which the risk of worse outcome of COVID-19 is increased. In a cross-sectional, observational, multicenter, nationwide Italian survey hypertension had higher prevalence in hospitalized patients, however non survivors to COVID-19 had hypertension along with older age, higher Charlson Comorbidity Index, higher prevalence of diabetes, and chronic obstructive pulmonary disease (COPD), chronic kidney disease (CKD), coronary artery diseases, and heart failure (HF). Hence, in a multivariate analysis after adjustment for age and other CV risk factors, hypertension did not play an independent role in COVID-19 development and outcome [3, 4]. In a French cohort of more than 87,000 people, cardiometabolic diseases, (including obesity, diabetes, hypertension, dyslipidaemia), CV disease (stroke and stroke sequelae, HF, $\mathrm{CAD}$, cardiac arrhythmias or conduction disorders, valvular heart disease, peripheral artery disease), chronic respiratory diseases and severe CKD were associated to a much higher risk of hospitalization for COVID-19 and of in-hospital mortality. The high comorbidity rate among patients hospitalized for COVID-19 pneumonia was up to $69 \%$ in those aged $>65$ years [5]. In a large cohort of patients in UK the hazard ratio for death compared to younger subjects increased from 2.63 (95\% confidence interval $[\mathrm{CI}] 2.06-3.35, \mathrm{P}<0.001$ ) in patients aged between 50 and 59 years and to $11.09(95 \%$ CI 8.93-13.77; $\mathrm{P}<0.001)$ in patients of at least 80 years old, and the influence of hypertension on mortality risk has been demonstrated to be less relevant after adjustment for age and sex, the hazard ratio changing from 1.09 (95\% CI $1.05-1.14$ ) to 0.89 (95\% CI 0.85-0.93) [9]. Therefore, these observations suggest that hypertension may not play and independent role in SARS-Cov-2 infection and COVID-19, rather, the effect of hypertension on COVID-19 course is influenced by older age and the interaction with other $\mathrm{CV}$ risk factors. Interestingly, in a retrospective single-center cohort study at the Seventh Hospital of Wuhan City, China, it has been showed that not the hypertensive status but only elevated systolic BP (SBP) values was associated with death and respiratory distress parameters. High SBP, was identified as a covariate in both mortality and survival prediction models and was present in deceased COVID-19 patients as compared to discharged individuals [19]. This is not surprising, since elevated SBP could be a marker of pre-existing hypertension mediated subclinical organ damage (HMOD, i.e. vascular stiffness), thus representing an important comorbidity factor [20]. Higher SBP could be also due to under-treated or uncontrolled hypertension or may represent a consequence of reduced enzymatic activity of angiotensin converting enzyme-2 (ACE2) caused by the binding of a higher SARS-CoV-2 load. It should be also noted that patients who died were older, and this further highlights the link of age with hypertension in the risk of worse outcome in COVID-19. Consistently, in a large Spanish cohort of 12,170 patients elevated $\mathrm{SBP}>140 \mathrm{mmHg}$ at admission has been identified as a predictor of all-cause mortality, particularly when associated with elevated pulse pressure $\geq 60 \mathrm{mmHg}$ (i.e. increased arterial stiffness) [21]. Taken together, these findings suggest that the role of basal and achieved BP control rather than hypertension per se could be considered as a prognostic factor in COVID-19. In such a context, the delay in the diagnosis of hypertension and in the initiation of specific BP-lowering treatments as well as the increase in therapeutic inertia related to the COVID19 outbreak may have also contributed to the worsening of BP control which may impact on the prognosis of SARSCoV-2 infection [22, 23]. In this regard, uncontrolled blood pressure values are involved in the development of vascular 
remodeling and vascular stiffness, which may contribute to the impact of hypertension on the outcome and mortality in patients with COVID-19 [24, 25]. Hypertension is a major risk factor for endothelial dysfunction and atherosclerosis. Thus, the presence of these subclinical conditions could impact on CV outcome in patients with COVID-19 [20]. Moreover, among the different pathophysiological changes in the $\mathrm{CV}$ system in hypertensive patients, left ventricular hypertrophy and fibrosis, associate eventually to HF with preserved ejection fraction (HFpEF), may contribute to the higher susceptibility to SARS-CoV-2-induced damage in the heart, including ischemic damage, and the development of atrial and ventricular arrhythmias [26]. Hypertension may also contribute to the development of CKD, which represents a predisposing condition to the progression of acute kidney injury in patients with severe COVID-19, and may impact on the prognosis [27].

Hence it is reasonable to argue that HMOD may exert an independent prognostic value by increasing the risk of mortality in COVID-19, although this assumption should be further elucidated.

\section{Relationship with Vascular Inflammation}

The relationship between hypertension and COVID-19 may involve common inflammatory pathways. Indeed, a large body of evidence supports the hypothesis that hypertension is associated with immune activation and oxidative stress, consisting in the production of reactive oxygen species (ROS), increased activity of NADPH oxidases, cell migration and adhesion to endothelial surface [28].

Both innate (i.e. macrophages, microglia, monocytes, dendritic cells, and myeloid-derived suppressor cells) and adaptive immune cells (i.e. CD8+ T cells, CD4+ cells [Th1, Th17 and Treg cells], T cells and B cells) have been shown to favor the development of hypertension in the context of COVID-19, particularly through the activation of the NLRP3-related inflammasome and the secretion of cytokines (e.g. interleukin-6, -7 and -17, interferon [IFN]gamma, and tumor necrosis factor [TNF]-alpha) [29-32]. These immune mechanisms also contribute significantly to accelerated end-organ damage. Immune dysregulation characterized by the increased levels of interleukin-2, -6 and -7 , granulocyte colony-stimulating factor, C-X-C motif chemokine 10, chemokine [C-C motif] ligand 2 and TNFalpha have been also associated with the severity of COVID19 [33]. COVID-19 is often associated to cytokine storm resulting in endotheliitis which induces vascular permeability, the secretion of adhesion molecules (such as ICAM-1, VCAM-1), TNF- $\alpha$, angiopoietin- 2 , eNOS downregulation, and decreases prostacyclin production. Moreover, it also induces capture of platelets and dysregulation of clotting cascades, thrombin activation, and fibrin production. Glycocalyx disruption and increased release of von-Willebrand factor (VWF) and factor VIII, usually stored in Weibel-Palade body of endothelial cells, have been also proposed as contributing factors of endothelial dysfunction and cloth formation. Conversely, the activation of angiopoietin 2 may countervail and act as an antagonist of Tie 2 activation by the angiopoietin 1, and induces anti-inflammatory, anticoagulatory, and antiapoptotic signaling [34]. Intravascular thrombosis and coagulation, in addition, may further damage the endothelium maintaining a vicious circle of endothelial inflammation and dysfunction. Extensive microthrombosis in coronary and pulmonary circulation have been described and are respectively associated to myocardial damage with increased troponin levels and to an unusual dead-space and shunt in the lung contributing to severe hypoxia and respiratory distress $[35,36]$. Autoptic analyses of patients who died for COVID-19 showed the presence of thrombi with a diameter of 1-2 $\mathrm{mm}$ in pulmonary precapillary vessels and a distorted vascularity with structurally deformed elongated capillaries with sudden changes in caliber and the presence of intussusceptive pillars. Clot formation was also detected in pulmonary arterioles with diffuse alveolar damage and hyaline membranes [37-40].

It should be noted that most of the abovementioned molecular pathways (including immune cells dysregulation, activation of ROS and inflammatory pathways) may be also involved in the pathophysiology of endothelial dysfunction in hypertension which might predispose to SARS-CoV-2 infection [41-45]. These common mechanisms may further contribute to explain the increased vulnerability of hypertensive patients to a more severe disease course when vascular damage occurs, although this hypothesis must be confirmed by future preclinical and clinical studies [20].

\section{The Role of Renin-Angiotensin System and RAS Blockers in COVID-19}

RAS and, in particular its key effector Ang II, plays a fundamental role in the development of hypertension and its sequelae, contributing to endothelial dysfunction, cell growth, oxidative stress, vasoconstriction and inflammation. Ang II induces hyperplasia and hypertrophy of vascular smooth muscle cells (VSMC) in resistance arteries and increases the production of mitogenic factors such as TGF- $\beta$, PDGF (platelet-derived growth factor), EGF (epidermal growth factor), IGF-1 (insulin-like growth factor 1) and of superoxide through the activation of cSrc, PKC, phospholipase A2 (PLA2) and phospholipase D (PLD). Moreover, Ang II enhances NADPH oxidase activity and the generation of ROS [46] which may activate several signaling pathways such as MAPK, JAK-2, STAT, p21Ras, 
Pyk-2 (Proline-rich Tyrosine Kinase 2) and AKT, receptor tyrosine kinases such as EGFR (EGF Receptor), IGFR (IGF Receptor 1) and PDGFR, protein tyrosine phosphatases and redox-sensitive transcriptor factors such as Activator Protein 1 (AP)-1 and Hypoxia-inducible factor 1 (HIF-1) [47, 48]. Ang II also stimulates the production of E-selectin and plasminogen activator inhibitor-1 (PAI-1), which may contribute to a prothrombotic state [49].

On the other hand, the activation of complementary protective axes in the RAS may countervail these deleterious effects in the CV system particularly during the use of RAS blockers. These include activation of the type 2 Ang II receptor (AT2R) which exerts a protective role in the $\mathrm{CV}$ system, inducing vasodilation, $\mathrm{NO}$ production and producing antiproliferative, anti-inflammatory and antiremodelling effects and the activation of ACE2/Ang-1-7/ MasReceptor (MasR) system [50]. The classical ACE, a dipeptidyl carboxypeptidase, converts the decapeptide angiotensin I (Ang 1-10) into the octapeptide angiotensin II (Ang 1-8), which is the main effector of the RAS. Another enzyme, homologous to ACE was identified, and named ACE2 which is a mono-carboxypeptidase, that cleaves one amino-acid at the end of peptides and forms another peptide from Ang II which contains only 7 amino acids, namely Ang (1-7), and cannot be inhibited by ACEi. Ang (1-7) activates the MasR and exerts a protective role on the $\mathrm{CV}$ system, mediating vasodilation, antioxidation, anti-fibrotic and anti-inflammatory effects [51-54]. Experimental studies have shown that the activation of ACE-2/Ang (1-7)/MasR axis may counteract, at least in in part, the Ang II effects in the CV system, such a vasoconstriction and cell growth, and may induce favorable effects on the function and structure of aorta and the heart. Furthermore, ACE-2/Ang (1-7)/MasR axis has been demonstrated to play an important role in microvascular protection during selective blockade of the AT1R through the improvement of resistance arteries remodeling via the reduction of ROS production and increased NO bioavailability [50]. MasR expression was significantly increased by Ang (1-7) as well as by ARB, increasing eNOS expression and plasma nitrite. On the other hand, superoxide generation was attenuated by ARB and Ang (1-7). These MasR-mediated actions were independent of AT2R activation and may contribute to the favorable effects of AT1R antagonism on NO bioavailability and microvascular remodeling, independently of AT2R activation and BP control [50].

Animal studies have shown that the development of HMOD is more common in case of a reduced expression of ACE2 mRNA [55-57]. Lentiviral gene transfer of ACE2 reduced $\mathrm{CV}$ damage in spontaneously hypertensive rats (SHR) [58]. Consistently, pharmacological activation of
ACE2 or administration of recombinant human ACE2 attenuated vascular damage in rat models [59].

Membrane ACE2 is also the key binding receptor promoting cell entry of SARS-CoV-2 in the respiratory tract [60]. In this regard, the RAS inhibitors-mediated increase of ACE2 has generated concern at the beginning of the COVID-19 outbreak due to the hypothesized increased risk of infection and of a more aggressive course of the disease [14]. Several studies, however, have demonstrated that ACE2 expression is low in the respiratory tract [61] and that the ACE2/Ang (1-7)/MasR axis exerts an important protective role against inflammatory lung injury, whereas an increased expression of Ang II and the activation AT1R may favor pulmonary damage [62]. The binding of the SARS-Cov-2 spike protein to ACE2, causing its downregulation, reduces the potentially protective effects during acute inflammation [38]. In animal models the administration of recombinant SARS virus spike protein alone, even in the absence of viral replication, downregulated ACE2 on the surface of pulmonary alveolar cells and concurred to lung injury [63]. In the early phases of COVID-19 outbreak an increasing debate developed on the use (withdrawal or maintenance) of drugs interacting with RAS, in particular angiotensin converting enzyme (ACE) inhibitors (ACEi) and angiotensin receptor blockers (ARBs) [13]. These drugs represent the first line therapy most frequently used in hypertensive patients as recommended by the international guidelines, due to their protective $\mathrm{CV}$ activity on the development of HMOD, atherosclerosis, HF, and chronic kidney disease [10-12]. However, on the basis of the abovementioned data, treatment with ACEIs and ARBs may even protect from a severe disease course through the inhibition of the deleterious proinflammatory e effect of AngII as well as through the activation of the protective arms of the RAS. Furthermore, it has been also demonstrated that ACE2 is not upregulated in nasal ciliary cells of patients who received ACEI or ARBs, independently from age, sex and smoking history [64]. In addition, treatment with ACEI has been associated with activation of intrinsic antiviral response [65]. In a study conducted in 436 patients the ACE2 mRNA expression was associated to age, but neither to hypertension nor to treatment with RAS inhibitors [66].

Several observational and cohort studies have shown the non-harmful effect or even the safety of the use of RAS blockers in COVID-19 patients. In an Italian populationbased study conducted by Mancia and colleagues, the use of RAS inhibitors was more frequent among the 6272 patients with COVID-19 compared to the 30,759 controls because of the higher prevalence of CV RFs and CVD. However, in multivariable adjusted analysis, the use of ARBs/ACEIs or their combination with other antihypertensive drugs was not significantly associated with the risk of COVID-19 or with a more severe disease course [67]. 
In another population-based study conducted in Spain on 1139 COVID-19 patients and on 11,390 matched controls, the use of RAS inhibitors was not associated to an increased risk of infection or with hospital admission [68]. In a Korean study, 950 out of 16,281 hypertensive patients experienced COVID-19 disease. Among them, those who were treated with ACEIs or ARBs did not present an increased risk of hospitalization, independently from the use of these drugs for hypertension or other causes after case-control matching and multivariable-adjusted conditional logistic regression analysis [69]. The analysis of these three population-based case-control studies confirmed the absence of significant association between ACEI/ARB (pooled odds ratio 1.00 [95\% CI 0.81-1.23], $\mathrm{P}=0.98)$ and all-cause mortality/severe disease [70].

In an observational analysis conducted by Reynolds and colleagues in a cohort of 12,594 subjects who were tested for COVID-19, among whom $46.8 \%$ resulted positive and $17.0 \%$ had severe illness, no association was found between the use of RAS blockers and an increased likelihood of a positive test or the risk of severe illness [17]. These results have been confirmed by another retrospective cohort study conducted on 18,472 subjects and by a large meta-analysis of 31 studies on 87,951 participants which showed no significant association between treatment with RAS inhibitors and all-cause mortality (risk ratio 0.94 [95\% CI 0.86-1.03], $\mathrm{P}=0.20$ ) or severe disease (risk ratio 0.93 [95\% CI 0.74-1.17], $\mathrm{P}=0.55$ ) [71]. In a study conducted by Morales and colleagues, 363,785 patients with hypertension treated with ACEIs or ARBs were compared with 24,8915 subjects who received calcium channel blockers of thiazidic diuretics, showing no association between the used antihypertensive agents, both as monotherapy or associations with other drugs, and COVID-19 diagnosis and hospitalization. Importantly, the direct comparison of ACEIs with ARBs also did not yield any apparent difference [72].

In the randomized BRACE-CORONA trial, 659 hospitalized patients with COVID-19 were assigned to continuation of ACEI/ARB treatment or temporary suspension of the therapy for 30 days. There were no significant differences among group in the primary outcome of the number of days alive and out of hospital at 30 days (21.9 vs 22.9 days in the discontinuation and continuation groups, respectively; average difference -1.1 days; mean ratio $0.95 ; 95 \%$ CI $0.90-1.01 ; \mathrm{P}=0.09)$. However, it should be underlined that the relatively low-risk (57\% had mild disease) and young age (mean 55.1 years) of the enrolled population and the low mortality rate $(2.7 \%)$ may have influenced the achieved results [73].

In the REPLACE-COVID trial 152 patients were randomly assigned to either continue or discontinue RAS-inhibitor therapy, showing no effects on the risk of intensive care unit admission, invasive mechanical ventilatory support and death [74].

In a cohort of hospitalized COVID-19 patients the ARB telmisartan significantly reduced C-reactive protein (CRP) levels and COVID-19 related outcomes, including ICU admission, time to discharge and death, compared to usual care. It should be noted that treatment with telmisartan was started early, within 4 days of symptom onset, and that it was administered at high dosages twice daily, suggesting that RAS inhibition might be adequately obtained with intensive strategies during COVID-19 disease [75].

In the ACEI-COVID trial 204 patients with recent symptomatic SARS-CoV-2 infection and chronically treated with ACEIs or ARBs were randomly assigned to discontinuation or continuation of RAS inhibition for 30 days. There were no significant differences among groups in the primary outcome of the maximum sequential organ failure assessment (SOFA) score within 30 days and in the secondary endpoints of area under the death-adjusted SOFA score (AUCSOFA), mean SOFA score, admission to the intensive care unit, mechanical ventilation, and death [76].

The ongoing RAMIC is assessing the efficacy of treatment with ramipril $2.5 \mathrm{mg}$ for 14 days to decrease ICU admission, mechanical ventilator use and mortality in patients with COVID-19 while also minimizing the risk of transmission and use of personal protective equipment [77].

Consistently, two other randomized trials are exploring the effects of the ARB losartan (NCT04312009) and of the mineralocorticoid receptor agonist spironolactone (NCT04345887) compared to placebo on morbidity and mortality during hospitalization for COVID-19.

In such a context, also angiotensin receptor/neprilysin inhibitors (ARNi), combining the blockade of AT1R and the ability to increase natriuretic peptide levels, which regulate cellular growth and proliferation, preserving endothelial function and integrity as well as vascular tone, might represent a potential therapeutic tool in the treatment of COVID19 [78].

Thus, on the basis of this evidence, international guidelines and expert consensus have repeatedly recommended to not discontinue treatment with RAS-inhibitors, eventually considering individual risk, comorbidities and the presence of organ damage [79, 80].

\section{COVID-19 and Other Antihypertensive Drugs}

The role of mineralocorticoid receptor antagonists (MRA) and other first-line antihypertensive drug classes, such as calcium channel blockers (CCBs), thiazides/thiazide-like diuretics, and $\beta$-blockers have been also evaluated. In the study by Mancia and colleagues, only 3.8\% of patients 
received MRA and no differences were observed in disease outcome compared to the control group [67].

It has been suggested that $\beta$-blockers may exert protective effects counterbalancing the activation of sympathetic system during COVID-19 disease. Moreover, individuals treated with $\beta$-blockers had a marginally lower likelihood of a positive COVID-19 test than patients not treated with these medications. Otherwise, a slightly higher risk of severe illness has been detected in subjects previously treated with CCBs [17].

Treatment with loop diuretics was apparently associated with an increased risk of COVID-19. However, the use of loop diuretics may be related to the existence of more severe comorbidities such as $\mathrm{HF}$ or advanced CKD, which may have influenced the results [67]. These findings further underline the important role of potential confounding by the concurrence and severity of comorbidities.

\section{Conclusions}

Current evidence suggests that even though hypertension is often present in COVID-19 patients, this pathological condition does not play and independent role in SARSCov-2 infection and COVID-19 progression. Rather, higher uncontrolled SBP may contribute to a more severe disease course, due to its association with HMOD, including vascular remodelling, which may worsen endothelial dysfunction, endothelial damage and endotheliitis induced by the SARS-Cov-2 infection. Although a large body of evidence supports the safety and even the protective role of the RAS blockers during COVID-19, further randomized clinical trials are required to confirm findings mostly deriving from observational studies and registries.

Finally many knowledge gaps remain to fill-up particularly with regard to the overall impact of hypertension on SARS-CoV-2 infection and the development of long-term sequelae such as post-COVID syndrome and long-COVID. In this perspective, hypertension still represents a "moving target" in COVID-19 management [20].

\section{Declarations}

Conflict of Interest On behalf of all authors, the corresponding author states that there is no conflict of interest.

Open Access This article is licensed under a Creative Commons Attribution-NonCommercial 4.0 International License, which permits any non-commercial use, sharing, adaptation, distribution and reproduction in any medium or format, as long as you give appropriate credit to the original author(s) and the source, provide a link to the Creative Commons licence, and indicate if changes were made. The images or other third party material in this article are included in the article's Creative Commons licence, unless indicated otherwise in a credit line to the material. If material is not included in the article's Creative Commons licence and your intended use is not permitted by statutory regulation or exceeds the permitted use, you will need to obtain permission directly from the copyright holder. To view a copy of this licence, visit http://creativecommons.org/licenses/by-nc/4.0/.

\section{References}

1. Blumenthal D, Fowler EJ, Abrams M, Collins SR. Covid19-implications for the health care system. N Engl J Med. 2020;383(15):1483-2148.

2. World Health Organization. WHO Coronavirus (COVID-19) dashboard. https://covid19.who.int. Accessed 21 Oct 2021.

3. Iaccarino G, Grassi G, Borghi C, Ferri C, Salvetti M, Volpe M, SARSRAS Investigators. Age and multimorbidity predict death among COVID-19 patients: results of the SARS-RAS Study of the Italian Society of hypertension. Hypertension. 2020;76:366-72.

4. Mancusi C, Grassi G, Borghi C, Carugo S, Fallo F, Ferri C, Giannattasio C, Grassi D, Letizia C, Minuz P, et al, SARS-RAS Investigators. Determinants of healing among patients with coronavirus disease 2019: the results of the SARS-RAS study of the Italian Society of hypertension. J Hypertens. 2021;39:376-80.

5. Semenzato L, Botton J, Drouin J, Cuenot F, Dray-Spira R, Weill A, Zureik M. Chronic diseases, health conditions and risk of COVID-19-related hospitalization and in-hospital mortality during the first wave of the epidemic in France: a cohort study of 66 million people. Lancet Reg Health Eur. 2021;8:100158.

6. Thakur B, Dubey P, Benitez J, Torres JP, Reddy S, Shokar N, Aung K, Mukherjee D, Dwivedi AK. A systematic review and meta-analysis of geographic differences in comorbidities and associated severity and mortality among individuals with COVID- 19 . Sci Rep. 2021;11(1):8562.

7. Vincent JL, Taccone FS. Understanding pathways to death in patients with COVID-19. Lancet Respir Med. 2020;8:430-2.

8. Deng G, Yin M, Chen X, Zeng F. Clinical determinants for fatality of 44,672 patients with COVID-19. Crit Care. 2020;24:179.

9. Docherty AB, Harrison EM, Green CA, Hardwick HE, Pius R, Norman L, Holden KA, Read JM, Dondelinger F, Carson G, et al, ISARIC4C investigators. Features of 20133 UK patients in hospital with covid-19 using the ISARIC WHO clinical characterisation protocol: prospective observational cohort study. BMJ. 2020;369:m1985.

10. Williams B, Mancia G, Spiering W, Agabiti Rosei E, Azizi M, Burnier M, Clement DL, Coca A, de Simone G, Dominiczak A, Kahan T, Mahfoud F, Redon J, Ruilope L, Zanchetti A, Kerins M, Kjeldsen SE, Kreutz R, Laurent S, Lip GYH, McManus R, Narkiewicz K, Ruschitzka F, Schmieder RE, Shlyakhto E, Tsioufis C, Aboyans V, Desormais I, ESC Scientific Document Group. $2018 \mathrm{ESC} / \mathrm{ESH}$ Guidelines for the management of arterial hypertension. Eur Heart J. 2018;39(33):3021-104.

11. Unger T, Borghi C, Charchar F, Khan NA, Poulter NR, Prabhakaran D, Ramirez A, Schlaich M, Stergiou GS, Tomaszewski M, et al. 2020 International Society of Hypertension global hypertension practice guidelines. J Hypertens. 2020;38:982-1004.

12. Whelton PK, Carey RM, Aronow WS, Casey DE Jr, Collins KJ, Dennison Himmelfarb C, DePalma SM, Gidding S, Jamerson KA, Jones DW, MacLaughlin EJ, Muntner P, Ovbiagele B, Smith SC Jr, Spencer CC, Stafford RS, Taler SJ, Thomas RJ, Williams KA Sr, Williamson JD, Wright JT Jr. 2017 ACC/AHA/AAPA/ABC/ ACPM/AGS/APhA/ASH/ASPC/NMA/PCNA guideline for the prevention, detection, evaluation, and management of high blood pressure in adults: a report of the American College of Cardiology/American Heart Association Task Force on clinical practice guidelines. J Am Coll Cardiol. 2018;71(19):e127-248. 
13. Kreutz R, Algharably EAE, Azizi M, Dobrowolski P, Guzik T, Januszewicz A, Persu A, Prejbisz A, Riemer TG, Wang JG, et al. Hypertension, the renin-angiotensin system, and the risk of lower respiratory tract infections and lung injury: implications for COVID-19. Cardiovasc Res. 2020;116:1688-99.

14. Hoffmann M, Kleine-Weber H, Schroeder S, Krüger N, Herrler T, Erichsen S, Schiergens TS, Herrler G, Wu NH, Nitsche A, et al. SARS-CoV-2 cell entry depends on ACE2 and TMPRSS2 and is blocked by a clinically proven protease inhibitor. Cell. 2020;181:271-280.e8.

15. Hoffmann M, Kleine-Weber H, Schroeder $\mathrm{S}$, KruÃàger N, Herrler T, Erichsen S, Schiergens TS, Herrler G, Wu NH, Nitsche A, et al. SARS-CoV-2 cell entry depends on ACE2 and TMPRSS2 and is blocked by a clinically proven protease inhibitor. Cell. 2020;181:271-280.e8.

16. Danser AHJ, Epstein M, Batlle D. Renin-angiotensin system blockers and the COVID-19 pandemic: at present there is no evidence to abandon renin-angiotensin system blockers. Hypertension. 2020;75(6):1382-5.

17. Reynolds HR, Adhikari S, Pulgarin C, Troxel AB, Iturrate E, Johnson SB, Hausvater A, Newman JD, Berger JS, Bangalore S, Katz SD, Fishman GI, Kunichoff D, Chen Y, Ogedegbe G, Hochman JS. Renin-angiotensin-aldosterone system inhibitors and risk of Covid-19. N Engl J Med. 2020;382(25):2441-8.

18. NCD Risk Factor Collaboration (NCD-RisC). Worldwide trends in hypertension prevalence and progress in treatment and control from 1990 to 2019: a pooled analysis of 1201 populationrepresentative studies with 104 million participants. Lancet. 2021;398(10304):957-80.

19. Caillon A, Zhao K, Klein KO, Greenwood C, Lu Z, Paradis P, Schiffrin EL. High systolic blood pressure at hospital admission is an important risk factor in models predicting outcome of COVID-19 patients. Am J Hypertens. 2021;34(3):282-90.

20. Savoia C, Volpe M, Kreutz R. Hypertension, a moving target in COVID-19: current views and perspectives. Circ Res. 2021;128(7):1062-79.

21. Rodilla E, López-Carmona MD, Cortes X, Cobos-Palacios L, Canales S, Sáez MC, Campos Escudero S, Rubio-Rivas M, Díez Manglano J, Freire Castro SJ, Vázquez Piqueras N, Mateo Sanchis E, Pesqueira Fontan PM, Magallanes Gamboa JO, González García A, Madrid Romero V, Tamargo Chamorro L, González Moraleja J, Villanueva Martínez J, González Noya A, Suárez-Lombraña A, Gracia Gutiérrez A, López Reboiro ML, Ramos Rincón JM, Gómez Huelgas R, SEMI-COVID-19 Network. Impact of arterial stiffness on all-cause mortality in patients hospitalized with COVID-19 in Spain. Hypertension. 2021;77(3):856-67.

22. Kreutz R, Dobrowolski P, Prejbisz A, Algharably EAE, Bilo G, Creutzig F, Grassi G, Kotsis V, Lovic D, Lurbe E, Modesti PA, Pappaccogli M, Parati G, Persu A, Polonia J, Rajzer M, de Timary P, Weber T, Weisser B, Tsioufis K, Mancia G, Januszewicz A, European Society of Hypertension COVID-19 Task Force Review. Lifestyle, psychological, socioeconomic and environmental factors and their impact on hypertension during the coronavirus disease 2019 pandemic. J Hypertens. 2021;39(6):1077-89.

23. Volpe M, Gallo G. COVID-19 and the forgotten majority. High Blood Press Cardiovasc Prev. 2020;27(5):339.

24. Safar ME, Asmar R, Benetos A, Blacher J, Boutouyrie P, Lacolley P, Laurent S, London G, Pannier B, Protogerou A, et al, French Study Group on Arterial Stiffness. Interaction between hypertension and arterial stiffness. Hypertension. 2018;72:796-805.

25. Battistoni A, Michielon A, Marino G, Savoia C. Vascular aging and central aortic blood pressure: from pathophysiology to treatment. High Blood Press Cardiovasc Prev. 2020;27:299-308.

26. Lala A, Johnson KW, Januzzi JL, Russak AJ, Paranjpe I, Richter F, Zhao S, Somani S, Van Vleck T, Vaid A, et al, Mount Sinai
COVID Informatics Center. Prevalence and impact of myocardial injury in patients hospitalized with COVID-19 infection. J Am Coll Cardiol. 2020;76:533-46.

27. Braun F, Lütgehetmann M, Pfefferle S, Wong MN, Carsten A, Lindenmeyer MT, Nörz D, Heinrich F, Meißner K, Wichmann D, Kluge S, Gross O, Pueschel K, Schröder AS, Edler C, Aepfelbacher M, Puelles VG, Huber TB. SARS-CoV-2 renal tropism associates with acute kidney injury. Lancet. 2020;396(10251):597-8

28. Patrick DM, Van Beusecum JP, Kirabo A. The role of inflammation in hypertension: novel concepts. Curr Opin Physiol. 2021;19:92-8.

29. Krishnan SM, Ling YH, Huuskes BM, Ferens DM, Saini N, Chan CT, Diep H, Kett MM, Samuel CS, Kemp-Harper BK, et al. Pharmacological inhibition of the NLRP3 inflammasome reduces blood pressure, renal damage, and dysfunction in salt-sensitive hypertension. Cardiovasc Res. 2019;115:776-87.

30. Siedlinski M, Jozefczuk E, Xu X, Teumer A, Evangelou E, Schnabel RB, Welsh P, Maffia P, Erdmann J, Tomaszewski M, et al. White blood cells and blood pressure: a Mendelian Randomization Study. Circulation. 2020;141:1307-17.

31. Itani HA, McMaster WG Jr, Saleh MA, Nazarewicz RR, Mikolajczyk TP, Kaszuba AM, Konior A, Prejbisz A, Januszewicz A, Norlander AE, et al. Activation of human T cells in hypertension: studies of humanized mice and hypertensive humans. Hypertension. 2016;68:123-32.

32. Youn JC, Yu HT, Lim BJ, Koh MJ, Lee J, Chang DY, Choi YS, Lee SH, Kang SM, Jang Y, et al. Immunosenescent $\mathrm{CD}^{+} \mathrm{T}$ cells and $\mathrm{C}-\mathrm{X}-\mathrm{C}$ chemokine receptor type 3 chemokines are increased in human hypertension. Hypertension. 2013;62:126-33.

33. Mehta P, McAuley DF, Brown M, Sanchez E, Tattersall RS, Manson JJ, HLH Across Speciality Collaboration, UK. COVID-19: consider cytokine storm syndromes and immunosuppression. Lancet. 2020;395:1033-1034.

34. Bikdeli B, Madhavan MV, Jimenez D, Chuich T, Dreyfus I, Driggin E, et al, Global COVID-19 Thrombosis Collaborative Group, Endorsed by the ISTH, NATF, ESVM, and the IUA, Supported by the ESC Working Group on Pulmonary Circulation and Right Ventricular Function. COVID-19 and thrombotic or thromboembolic disease: implications for prevention, antithrombotic therapy, and follow-up: JACC state-of-the-art review. J Am Coll Cardiol. 2020;75(23):2950-73.

35. Lindner D, Fitzek A, Bräuninger H, Aleshcheva G, Edler C, Meissner K, Scherschel K, Kirchhof P, Escher F, Schultheiss HP, Blankenberg S, Püschel K, Westermann D. Association of cardiac infection with SARS-CoV-2 in confirmed COVID-19 autopsy cases. JAMA Cardiol. 2020;5(11):1281-5.

36. Gattinoni L, Coppola S, Cressoni M, Busana M, Rossi S, Chiumello D. COVID-19 does not lead to a "typical" acute respiratory distress syndrome. Am J Respir Crit Care Med. 2020;201(10):1299-300.

37. Ackermann M, Verleden SE, Kuehnel M, Haverich A, Welte T, Laenger F, Vanstapel A, Werlein C, Stark H, Tzankov A, et al. Pulmonary vascular endothelialitis, thrombosis, and angiogenesis in Covid-19. N Engl J Med. 2020;383:120-8. https://doi.org/10. 1056/NEJMoa2015432.

38. Evans PC, Rainger GE, Mason JC, Guzik TJ, Osto E, Stamataki Z, Neil D, Hoefer IE, Fragiadaki M, Waltenberger J, et al. Endothelial dysfunction in COVID-19: a position paper of the ESC working group for atherosclerosis and vascular biology, and the ESC council of basic cardiovascular science. Cardiovasc Res. 2020;116:2177-84.

39. Varga Z, Flammer AJ, Steiger P, Haberecker M, Andermatt R, Zinkernagel AS, Mehra MR, Schuepbach RA, Ruschitzka F, Moch H. Endothelial cell infection and endotheliitis in COVID-19. Lancet. 2020;395:1417-8. 
40. Fox SE, Lameira FS, Rinker EB, Vander Heide RS. Cardiac endotheliitis and multisystem inflammatory syndrome after covid19. Ann Intern Med. 2020;173:1025-7.

41. Savoia C, Schiffrin EL. Inflammation in hypertension. Curr Opin Nephrol Hypertens. 2006;15:152-8.

42. Savoia C, Schiffrin EL. Vascular inflammation in hypertension and diabetes: molecular mechanisms and therapeutic interventions. Clin Sci (Lond). 2007;112(7):375-84.

43. Savoia C, Sada L, Zezza L, Pucci L, Lauri FM, Befani A, Alonzo A, Volpe M. Vascular inflammation and endothelial dysfunction in experimental hypertension. Int J Hypertens. 2011;2011:281240.

44. Caillon A, Paradis P, Schiffrin EL. Role of immune cells in hypertension. Br J Pharmacol. 2019;176(12):1818-28.

45. Jin Y, Ji W, Yang H, Chen S, Zhang W, Duan G. Endothelial activation and dysfunction in COVID-19: from basic mechanisms to potential therapeutic approaches. Signal Transduct Target Ther. 2020;5(1):293

46. Touyz RM, Rios FJ, Alves-Lopes R, Neves KB, Camargo LL, Montezano AC. Oxidative stress: a unifying paradigm in hypertension. Can J Cardiol. 2020;36(5):659-70.

47. La Favor JD, Dubis GS, Yan H, White JD, Nelson MA, Anderson EJ, Hickner RC. Microvascular endothelial dysfunction in sedentary, obese humans is mediated by NADPH oxidase: influence of exercise training. Arterioscler Thromb Vasc Biol. 2016;36(12):2412-20.

48. Godo S, Shimokawa H. Divergent roles of endothelial nitric oxide synthases system in maintaining cardiovascular homeostasis. Free Radic Biol Med. 2017;109:4-10.

49. Touyz RM, Tabet F, Schiffrin EL. Redox-dependent signalling by angiotensin II and vascular remodelling in hypertension. Clin Exp Pharmacol Physiol. 2003;30(11):860-6.

50. Savoia C, Arrabito E, Parente R, Nicoletti C, Madaro L, Battistoni A, Filippini A, Steckelings UM, Touyz RM, Volpe M. Mas receptor activation contributes to the improvement of nitric oxide bioavailability and vascular remodeling during chronic AT1R (Angiotensin Type-1 Receptor) blockade in experimental hypertension. Hypertension. 2020;76:1753-61.

51. Lavandero S. Counter-regulatory renin-angiotensin system in cardiovascular disease. Nat Rev Cardiol. 2020;17:116-29.

52. Santos RAS, Sampaio WO, Alzamora AC, Motta-Santos D, Alenina N, Bader M, Campagnole-Santos MJ. The ACE2/Angiotensin-(1-7)/MAS axis of the renin-angiotensin system: focus on angiotensin-(1-7). Physiol Rev. 2018;98:505-53.

53. Savoia C, D'Agostino M, Lauri F, Volpe M. Angiotensin type 2 receptor in hypertensive cardiovascular disease. Curr Opin Nephrol Hypertens. 2011;20:125-32.

54. Kuriakose J, Montezano AC, Touyz RM. ACE2/Ang-(1-7)/Mas1 axis and the vascular system: vasoprotection to COVID-19-associated vascular disease. Clin Sci (Lond). 2021;135:387-407.

55. Kamilic J, Hamming I, Kreutz R, Bolbrinker J, Siems WE, Nassar I, Sluimer JC, Walther T, Navis GJ, van Goor H. Renal ACE2 expression and activity is unaltered during established hypertension in adult SHRSP and TGR(mREN2)27. Hypertens Res. 2010;33:123-8.

56. Patel SK, Velkoska E, Freeman M, Wai B, Lancefield TF, Burrell LM. From gene to protein-experimental and clinical studies of ACE2 in blood pressure control and arterial hypertension. Front Physiol. 2014;5:227.

57. Rentzsch B, Todiras M, Iliescu R, Popova E, Campos LA, Oliveira ML, Baltatu OC, Santos RA, Bader M. Transgenic angiotensinconverting enzyme 2 overexpression in vessels of SHRSP rats reduces blood pressure and improves endothelial function. Hypertension. 2008;52:967-73.

58. Díez-Freire C, Vázquez J, Correa de Adjounian MF, Ferrari MF, Yuan L, Silver X, Torres R, Raizada MK. ACE2 gene transfer attenuates hypertension-linked pathophysiological changes in the SHR. Physiol Genom. 2006;27:12-9.

59. Lo J, Patel VB, Wang Z, Levasseur J, Kaufman S, Penninger JM, Oudit GY. Angiotensin-converting enzyme 2 antagonizes angiotensin II-induced pressor response and NADPH oxidase activation in Wistar-Kyoto rats and spontaneously hypertensive rats. Exp Physiol. 2013;98:109-22.

60. Lan J, Ge J, Yu J, Shan S, Zhou H, Fan S, Zhang Q, Shi X, Wang Q, Zhang L, et al. Structure of the SARS-CoV-2 spike receptor-binding domain bound to the ACE2 receptor. Nature. 2020;581:215-20.

61. Hikmet F, Méar L, Edvinsson Å, Micke P, Uhlén M, Lindskog C. The protein expression profile of ACE2 in human tissues. Mol Syst Biol. 2020;16:e9610.

62. Kjeldsen SE, Narkiewicz K, Burnier M, Oparil S. Potential protective effects of antihypertensive treatments during the Covid19 pandemic: from inhibitors of the renin-angiotensin system to beta-adrenergic receptor blockers. Blood Press. 2021;30:1-3.

63. Jia H, Yue X, Lazartigues E. ACE2 mouse models: a toolbox for cardiovascular and pulmonary research. Nat Commun. 2020;11(1):5165.

64. Lee IT, Nakayama T, Wu CT, Goltsev Y, Jiang S, Gall PA, Liao CK, Shih LC, Schürch CM, McIlwain DR, et al. ACE2 localizes to the respiratory cilia and is not increased by ACE inhibitors or ARBs. Nat Commun. 2020;11:5453.

65. Trump S, Lukassen S, Anker MS, Chua RL, Liebig J, Thürmann L, Corman VM, Binder M, Loske J, Klasa C, Krieger T, Hennig BP, Messingschlager M, Pott F, Kazmierski J, Twardziok S, Albrecht JP, Eils J, Hadzibegovic S, Lena A, Heidecker B, Bürgel T, Steinfeldt J, Goffinet C, Kurth F, Witzenrath M, Völker MT, Müller SD, Liebert UG, Ishaque N, Kaderali L, Sander LE, Drosten C, Laudi S, Eils R, Conrad C, Landmesser U, Lehmann I. Hypertension delays viral clearance and exacerbates airway hyperinflammation in patients with COVID-19. Nat Biotechnol. 2021;39(6):705-16.

66. Jiang X, Eales JM, Scannali D, Nazgiewicz A, Prestes P, Maier M, Denniff M, Xu X, Saluja S, Cano-Gamez E, et al. Hypertension and renin-angiotensin system blockers are not associated with expression of angiotensin-converting enzyme 2 (ACE2) in the kidney. Eur Heart J. 2020;41:4580-8.

67. Mancia G, Rea F, Ludergnani M, Apolone G, Corrao G. Reninangiotensin-aldosterone system blockers and the risk of Covid-19. N Engl J Med. 2020;382(25):2431-40.

68. de Abajo FJ, Rodríguez-Martín S, Lerma V, Mejía-Abril G, Aguilar M, García-Luque A, Laredo L, Laosa O, Centeno-Soto GA, Ángeles Gálvez M, et al, MED-ACE2-COVID19 study group. Use of renin-angiotensin-aldosterone system inhibitors and risk of COVID-19 requiring admission to hospital: a case-population study. Lancet. 2020;395:1705-14.

69. Son M, Seo J, Yang S. Association between renin-angiotensinaldosterone system inhibitors and COVID-19 infection in South Korea. Hypertension. 2020;76:742-9.

70. Bavishi C, Whelton PK, Mancia G, Corrao G, Messerli FH. Renin-angiotensin-system inhibitors and all-cause mortality in patients with COVID-19: a systematic review and meta-analysis of observational studies. J Hypertens. 2021;39(4):784-94.

71. Mehta N, Kalra A, Nowacki AS, Anjewierden S, Han Z, Bhat P, Carmona-Rubio AE, Jacob M, Procop GW, Harrington S, et al. Association of use of angiotensin-converting enzyme inhibitors and angiotensin ii receptor blockers with testing positive for coronavirus disease 2019 (COVID-19). JAMA Cardiol. 2020;5:1020-6.

72. Morales DR, Conover MM, You SC, Pratt N, Kostka K, DuarteSalles T, Fernández-Bertolín S, Aragón M, DuVall SL, Lynch K, Falconer T, van Bochove K, Sung C, Matheny ME, Lambert CG, Nyberg F, Alshammari TM, Williams AE, Park RW, 
Weaver J, Sena AG, Schuemie MJ, Rijnbeek PR, Williams RD, Lane JCE, Prats-Uribe A, Zhang L, Areia C, Krumholz HM, Prieto-Alhambra D, Ryan PB, Hripcsak G, Suchard MA. Reninangiotensin system blockers and susceptibility to COVID-19: an international, open science, cohort analysis. Lancet Digit Health. 2021;3(2):e98-114.

73. Lopes RD, Macedo AVS, de Barros E Silva PGM, Moll-Bernardes RJ, Dos Santos TM, Mazza L, Feldman A, D’Andréa Saba Arruda G, de Albuquerque DC, Camiletti AS, de Sousa AS, de Paula TC, Giusti KGD, Domiciano RAM, Noya-Rabelo MM, Hamilton AM, Loures VA, Dionísio RM, Furquim TAB, De Luca FA, Dos Santos Sousa IB, Bandeira BS, Zukowski CN, de Oliveira RGG, Ribeiro NB, de Moraes JL, Petriz JLF, Pimentel AM, Miranda JS, de Jesus Abufaiad BE, Gibson CM, Granger CB, Alexander JH, de Souza OF, BRACE CORONA Investigators. Effect of discontinuing vs continuing angiotensin-converting enzyme inhibitors and angiotensin II receptor blockers on days alive and out of the hospital in patients admitted with COVID-19: a randomized clinical trial. JAMA. 2021;325(3):254-64.

74. Cohen JB, Hanff TC, William P, Sweitzer N, Rosado-Santander NR, Medina C, Rodriguez-Mori JE, Renna N, Chang TI, CorralesMedina V, Andrade-Villanueva JF, Barbagelata A, CristoduloCortez R, Díaz-Cucho OA, Spaak J, Alfonso CE, Valdivia-Vega R, Villavicencio-Carranza M, Ayala-García RJ, Castro-Callirgos CA, González-Hernández LA, Bernales-Salas EF, Coacalla-Guerra JC, Salinas-Herrera CD, Nicolosi L, Basconcel M, Byrd JB, Sharkoski T, Bendezú-Huasasquiche LE, Chittams J, Edmonston DL, Vasquez CR, Chirinos JA. Continuation versus discontinuation of renin-angiotensin system inhibitors in patients admitted to hospital with COVID-19: a prospective, randomised, open-label trial. Lancet Respir Med. 2021;9(3):275-84.

75. Duarte M, Pelorosso F, Nicolosi LN, Salgado MV, Vetulli H, Aquieri A, Azzato F, Castro M, Coyle J, Davolos I, Criado IF, Gregori R, Mastrodonato P, Rubio MC, Sarquis S, Wahlmann F,
Rothlin RP. Telmisartan for treatment of Covid-19 patients: an open multicenter randomized clinical trial. EClinicalMedicine. 2021;37:100962.

76. Bauer A, Schreinlechner M, Sappler N, Dolejsi T, Tilg H, Aulinger BA, Weiss G, Bellmann-Weiler R, Adolf C, Wolf D, Pirklbauer M, Graziadei I, Gänzer H, von Bary C, May AE, Wöll E, von Scheidt W, Rassaf T, Duerschmied D, Brenner C, Kääb S, Metzler B, Joannidis M, Kain HU, Kaiser N, Schwinger R, Witzenbichler B, Alber H, Straube F, Hartmann N, Achenbach S, von Bergwelt-Baildon M, von Stülpnagel L, Schoenherr S, Forer L, Embacher-Aichhorn S, Mansmann U, Rizas KD, Massberg S, ACEI-COVID Investigators. Discontinuation versus continuation of renin-angiotensin-system inhibitors in COVID-19 (ACEICOVID): a prospective, parallel group, randomised, controlled, open-label trial. Lancet Respir Med. 2021;9(8):863-72.

77. Ajmera V, Thompson WK, Smith DM, Malhotra A, Mehta RL, Tolia V, Yin J, Sriram K, Insel PA, Collier S, Richards L, Loomba R. RAMIC: design of a randomized, double-blind, placebo-controlled trial to evaluate the efficacy of ramipril in patients with COVID-19. Contemp Clin Trials. 2021;103:106330.

78. Rubattu S, Gallo G, Volpe M. A contemporary view of natriuretic peptides in the SARS-CoV-2 era. Front Physiol. 2021;12:643721.

79. The European Society for Cardiology. ESC guidance for the diagnosis and management of CV disease during the COVID-19 pandemic. https://www.escardio.org/Education/COVID-19-and-Cardi ology/ESC-COVID-19-Guidance. Accessed 21 Apr 2020.

80. Volpe M, Battistoni A, Bellotti P, Bellone S, Bertolotti M, Biffi A, Consoli A, Corsini A, Desideri G, Ferri C, et al, Board of the Italian Society of Cardiovascular Prevention. Recommendations for cardiovascular prevention during the Sars-Cov-2 pandemic: an executive document by the board of the Italian Society of cardiovascular prevention. High Blood Press Cardiovasc Prev. 2020;27:373-7. 